[Agr. Biol. Chem., Vol. 36, No. 4, p. 651 657, 1972]

\title{
Studies on $\gamma$ Globulin of Rice Embryo
}

\section{Part VI. Molecular Dimension and Chemical Composition of $\gamma_{3}$ Globulin}

\author{
By Yuhei Morita and Masako Horikoshi* \\ The Research Institute for Food Science, Kyoto \\ University, Kyoto
}

Received October 11, 1971

\begin{abstract}
The molecular weight of $\gamma_{3}$ globulin was determined to be 120,000 daltons by means of both sedimentation equilibrium and gel filtration methods. The protein was composed of 3 identical major and 1 minor subunits, and the molecular weights of them were found to be 35,000 and 13,000 daltons, respectively, by sodium dodecyl sulfate-polyacrylamide gel electrophoresis. The major subunit has an arginyl residue as the amino terminal amino acid. The amino acid and carbohydrate composition of $\gamma_{3}$ globulin was determined as follows: Lys ${ }_{37} \mathrm{His}_{37} \mathrm{Arg}_{92} \mathrm{Asp}_{60} \mathrm{Glu}_{139} \mathrm{Gly}_{120} \mathrm{Ala}_{83} \mathrm{Val}_{76} \mathrm{Leu}_{70} \mathrm{Ile}_{31} \mathrm{Pro}_{54} \mathrm{Ser}_{77} \mathrm{Thr}_{33}$ Cys $_{11}$ Met $_{9}$ Phe $_{51}$ Tyr $_{26} \operatorname{Trp}_{8}$ (Amide $\mathrm{NH}_{3}$ ) ${ }_{69}$ Hexose $_{15}$ Pentose $_{4}$ Hexosamine $_{4}$. The structure of $\gamma_{3}$ globulin was discussed with comparing that of $\gamma_{1}$ globulin.
\end{abstract}

Morita and Yoshida" found that rice embryo contained $r$ globulin or $7 \mathrm{~S}$ globulin as a major component protein similar to other seed embryo of the Gramineae. ${ }^{2,31}$ Soon after Sawai and Morita ${ }^{4)}$ demonstrated in gel electrophoretic and chromatographic experiments that the protein was not homogeneous but it was composed of three distinct components, i.e. $\gamma_{1}, \gamma_{2}$ and $\gamma_{3}$ globulins. The latter authors studied physicochemical properties and chemical composition of the purified $\gamma_{1}$ globulin which showed a very complex subunit composition of the protein. ${ }^{5 \sim 7}$ On the other hand, the investigation showed that $\gamma_{2}$ and $\gamma_{3}$ globulins seemed to have simpler subunit compositions in respect to the amino termini. This fact suggests that $\gamma_{2}$ and $\gamma_{3}$ globulins may be quite different from $\gamma_{1}$ globulin in their structure and function.

The present paper describes the molecular dimension, subunit structure and chemical

\footnotetext{
* Present address: Faculty of Education, Shiga University, Otsu.
}

composition of $\gamma_{3}$ globulin, compared with those of $\gamma_{1}$ globulin.

\section{MATERIALS AND METHODS}

Materials. $\gamma_{1}, \gamma_{2}$ and $\gamma_{3}$ Globulins were prepared according to the method of Sawai and Morita described in previous papers.1.4 As we have found that these globulins easily associated to form the dimers and tetramers during storage in concentrated ammonium sulfate solutions, the monomers of proteins were purified by gel filtration chromatography on a Sephadex G-200 column immediately before use. SCyanoethyl derivatives of globulins were prepared according to Beckwith et al.8,9\}

Sedimentation. Sedimentation analysis was performed with a Spinco model $\mathrm{E}$ analytical ultracentrifuge at $20^{\circ} \mathrm{C}$. Sedimentation velocity was determined at $59,780 \mathrm{rpm}$, and the values were corrected to $s_{20, \mathrm{w}}$. The analysis of S-cyanoethyl derivatives in $8 \mathrm{M}$ urea solution was carried out at a rotor speed of 42,040 rpm. For the determination of molecular weight the sedimentation equilibrium method of Fujita10 was carried out at a rotor speed of $7,928 \mathrm{rpm}$ at $20^{\circ} \mathrm{C}$. The calculation of molecular weight and sedimenta- 
tion coefficient of $\gamma_{3}$ globulin were performed by using the partial specific volume, $v$-, of $0.725 \mathrm{~cm}^{3} \mathrm{~g}^{-1}$, which was derived from the amino acid composition of the protein.

Viscosity. Viscosity measurements were carried out with an Ubbelohde viscometer having the flow time of $118 \mathrm{sec}$ with $2 \mathrm{ml}$ of water at $20 \pm 0.01^{\circ} \mathrm{C}$.

Spectrophotometry. Light absorption was determined by a Beckman DU spectrophotometer, and spectra were measured by a Hitachi EPS-2 recording spectrophotometer.

Gel filtration chromatography. The molecular weight of protein was determined by gel filtration on a Sephadex G-200 column, $2.5 \times 90 \mathrm{~cm}$, equilibrated with $0.08 \mathrm{M}$ phosphate buffer containing $0.8 \mathrm{M}$ sodium chloride, $\mathrm{pH}$ 6.84.11) As the molecular weight standards the following proteins were purchased and used without further purification: bovine serum albumin from Sigma, bovine serum $\gamma$ globulin (Cohn Fraction II) from Armour Pharmaceutical Co., rabbit muscle aldolase from Boehringer, horse apoferritin from Mann Research Laboratories and jackbean urease from E. Merck AG.

Polyacrylamide gel electrophoresis. Polyacrylamide gel electrophoresis was carried out in a horizontal gel apparatus, as described in the previous paper.4) Runs were conducted for $4 \mathrm{hr}$ at an electric current of $12.9 \mathrm{~mA}$ per $\mathrm{cm}^{2}$ of gel cross section.

Sodium dodecyl sulfate-polyacrylamide gel electrophoresis. Sodium dodecyl sulfate (SDS)-polyacrylamide gel electrophoresis was performed according to the method of
Shapiro et al.,12) modified by Weber and Osborn,13) for the determination of molecular weights of subunits. Bovine liver catalase and bovine pancreatic chymotrypsinogen A from Sigma, rabbit muscle aldolase from Boehringer and horse heart metmyoglobin from Calbiochem were used as the molecular weight standards.

Chemical analyses. Nitrogen was determined by the semimicro Kjeldahl method. ${ }^{5}$ The detection and the determination of hexose and pentose were carried out by the combination of the Bial's and Tillman's reactions assuming hexose as D-mannose and pentose as D-xylose. ${ }^{5}$

Amino acid analysis was carried out by means of a Yanagimoto model LG-2 automatic amino acid analyzer according to the method of Spackman et al.14) Half cystine was determined as cysteic acid ${ }^{15}$ and tryptophan and tyrosine were determined by the spectrophotometric method of Goodwin and Morton. ${ }^{16}$ The experimental details were the same as the case of $\gamma_{1}$ globulin reported in the previous paper.51

The determination of amino terminal amino acids was performed by the fluorodinitrobenzene (FDNB) method 17) with two-dimensional paper-chromatographic technique of Levy.18) Dinitrophenyl (DNP)-arginine was detected by spraying the Sakaguchi reagent ${ }^{19}$ ? and determined by the Sakaguchi reaction according to Weber. ${ }^{201}$

\section{RESULTS}

\section{Molecular dimension of $\gamma_{3}$ globulin}

Purified $\gamma_{3}$ globulin showed a single boundary

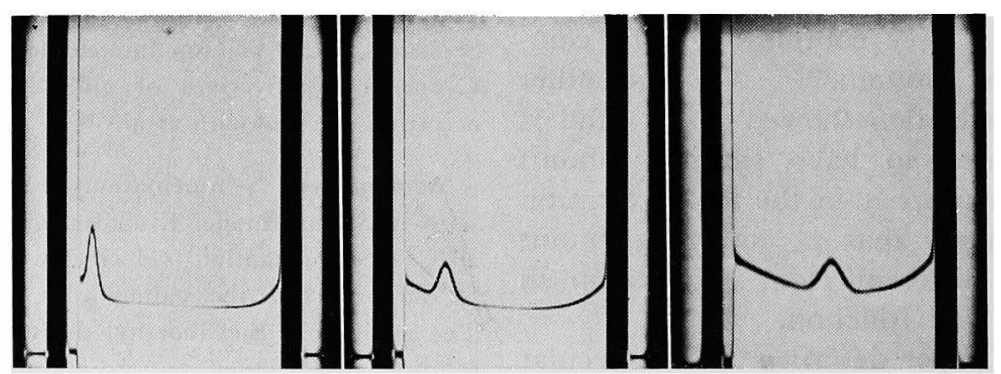

FIG. 1. Sedimentation Patterns of $\gamma_{3}$ Globulin in $0.08 \mathrm{M}$ Phosphate Buffer Containing $0.8 \mathrm{M}$ Sodium Chloride, $\mathrm{pH} 6.84$, at $20^{\circ} \mathrm{C}$.

Protein concentration was $2.47 \mathrm{mg} / \mathrm{ml}$. Photographs were taken at 10,34 and $82 \mathrm{~min}$ after reaching $59,780 \mathrm{rpm}$ (from left to right). 


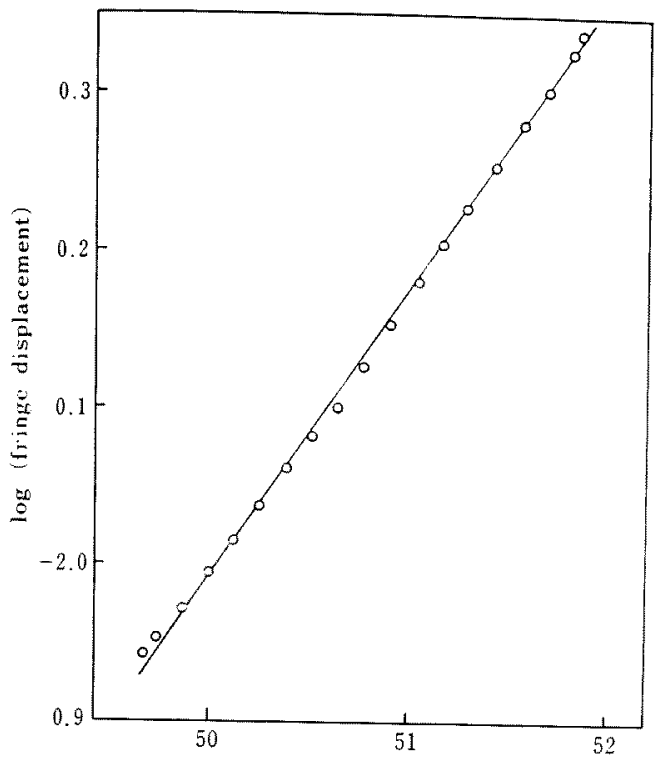

(Distance from center of rotor) ${ }^{2}$

Fig. 2. Determination of Molecular Weight of $\gamma_{3}$ Globulin by Sedimentation Equilibrium at $20^{\circ} \mathrm{C}$.

Protein was dissolved in $0.08 \mathrm{M}$ phosphate buffer containing $0.8 \mathrm{M}$ sodium chloride, $\mathrm{pH} 6.84$. Protein concentration was $1.24 \mathrm{mg} / \mathrm{ml}$. Rotor speed was $7,928 \mathrm{rpm}$, and the photograph was taken after $20 \mathrm{hr}$.

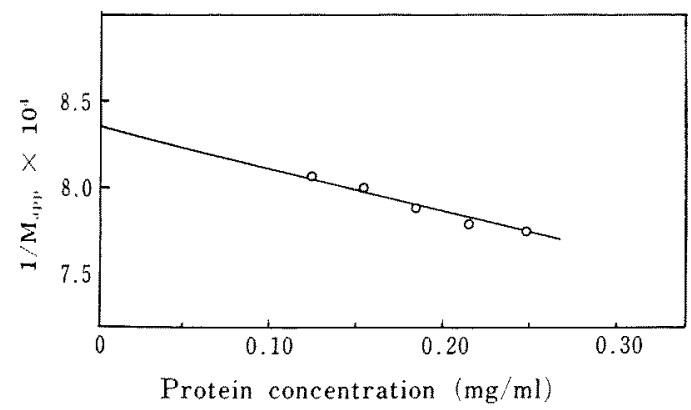

FIG. 3. Concentration Dependence of Reciprocal of Apparent Molecular Weight of $\gamma_{3}$ Globulin.

in the sedimentation analysis, as shown in Fig. 1, and exhibited the sedimentation coefficient, $s_{20, w}$, of $7.1 \mathrm{~S}$ at a protein concentration of $2.47 \mathrm{mg} / \mathrm{ml}$. The molecular weight of $\gamma_{3}$ globulin was determined by the sedimentation equilibrium method. Figure 2 shows the re-

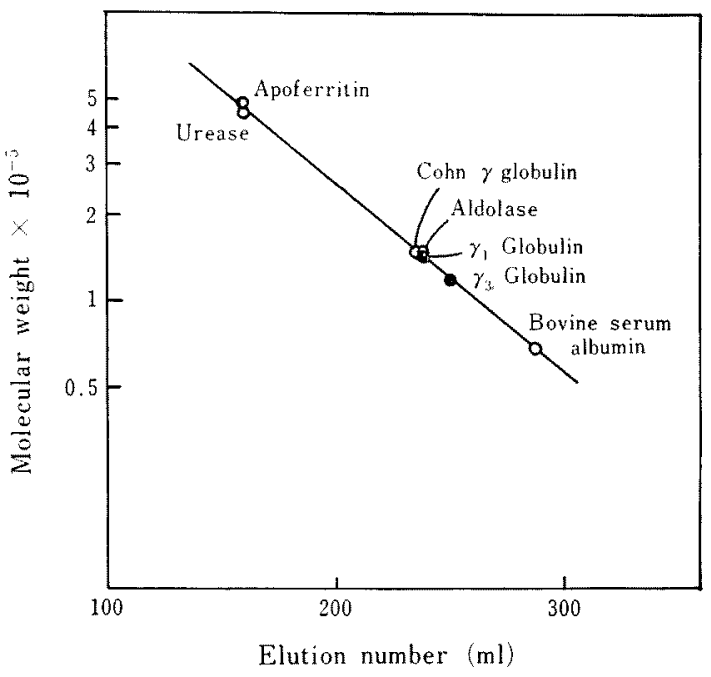

FIG. 4. Determination of Molecular Weight of $\gamma_{3}$ Globulin by Gel Filtration Chromatography on a Sephadex G-200 Column, $2.5 \times 90 \mathrm{~cm}$.

Experimental details are given in the text.

sult at a protein concentration of $1.24 \mathrm{mg} / \mathrm{ml}$, and Fig. 3 shows a plot of the reciprocal of apparent molecular weight against protein concentration, which gives the molecular weight of 120,000 daltons for $\gamma_{3}$ globulin. The same value of the molecular weight was obtained also by the gel filtration method. Figure 4 shows a semilogarithmic plot of molecular weight against the elution volume from a Sephadex G-200 column. The molecular weight of $\gamma_{3}$ globulin was found to be 120,000 daltons compared with the value for $r_{1}$ globulin, 140,000 daltons. The intrinsic viscosity of $\gamma_{3}$

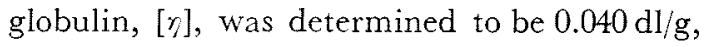
and the frictional ratio calculated from the following formula, $f / f_{0}=(1-\bar{v} \rho)\left(4 \pi M^{2}\right)^{1 / 3} /$ $6 \pi \eta s\left(3 \bar{v} N^{2}\right)^{1 / 3}$, is 1.1. The axial ratio of $\gamma_{3}$ globulin calculated by the Perrin's equation ${ }^{21}$ is almost equal to unity, assuming the molecule of a prolate ellipsoid of revolution with 30,6 hydration.

\section{Subunit structure of $\gamma_{3}$ globulin}

As described in the previous paper, ${ }^{4 !}$ the 
determination of N-terminal amino acid analysis showed that $\gamma_{3}$ globulin as well as $\gamma_{1}$ globulin seems to be composed of multiple subunits. Then we tried to elucidate the molecular weight of the subunits of $\gamma_{3}$ globulin. Figure 5 shows the sedimentation patterns of the S-

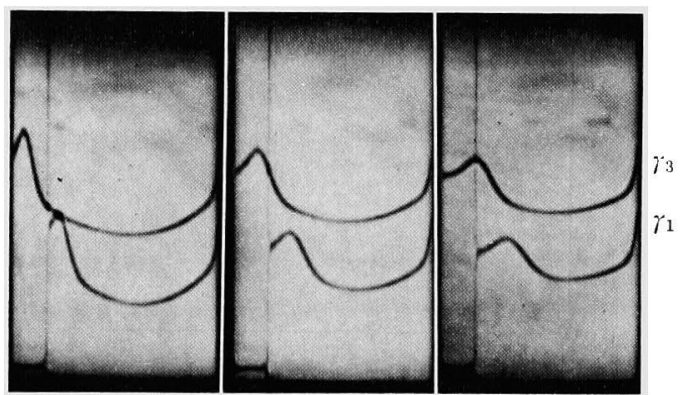

FIG. 5. Sedimentation Patterns of S-Cyanoethyl $r_{1}$ and $\gamma_{3}$ Globulins in $8 \mathrm{M}$ Urea at $\mathrm{pH} 7.62$ at $20^{\circ} \mathrm{C}$.

The sedimentation proceeds from left to right. The photographs were taken at 215, 285 and 405 min after reaching the maximum speed, 42,040 rpm. Protein concentrations of $\gamma_{1}$ and $\gamma_{3}$ globulins were 6.2 and $6.4 \mathrm{mg} / \mathrm{ml}$, respectively. cyanoethyl derivative of $\gamma_{3}$ globulin in $8 \mathrm{M}$ urea solution, $\mathrm{pH} 7.62$, together with those of of $\gamma_{1}$ globulin. The S-cyanoethyl derivative in $8 \mathrm{M}$ urea exhibited the sedimentation coefficient of about $2 \mathrm{~S}$ for both globulins, which shows that both globulins dissociate into subunits under the conditions. Figure 6 shows the electropherograms of S-cyanoethyl $\gamma_{3}$ globulin in the presence of $8 \mathrm{M}$ urea at $\mathrm{pH} 4.75$ and 10.0 , together with those of $\gamma_{1}$ globulin derivative. As seen from the figure, $\gamma_{1}$ globulin was composed of several kinds of subunit, while $\gamma_{3}$ globulin exhibits one major band and two minor bands in the cathodic side. The result is also coincided with the $\mathrm{N}$-terminal amino acid analysis, which gave 3.14 moles DNP-arginine, 0.35 mole DNP-glycine and 0.24 mole DNP-glutamic acid for $120,000 \mathrm{~g}$ of $\gamma_{3}$ globulin. The molecular weights of subunits determined by SDS-polyacrylamide gel electrophoresis are compatible with the above experimental results. Figure 7 shows the electropherograms of $\gamma_{1}$ and $\gamma_{3}$ globulins, and Fig.

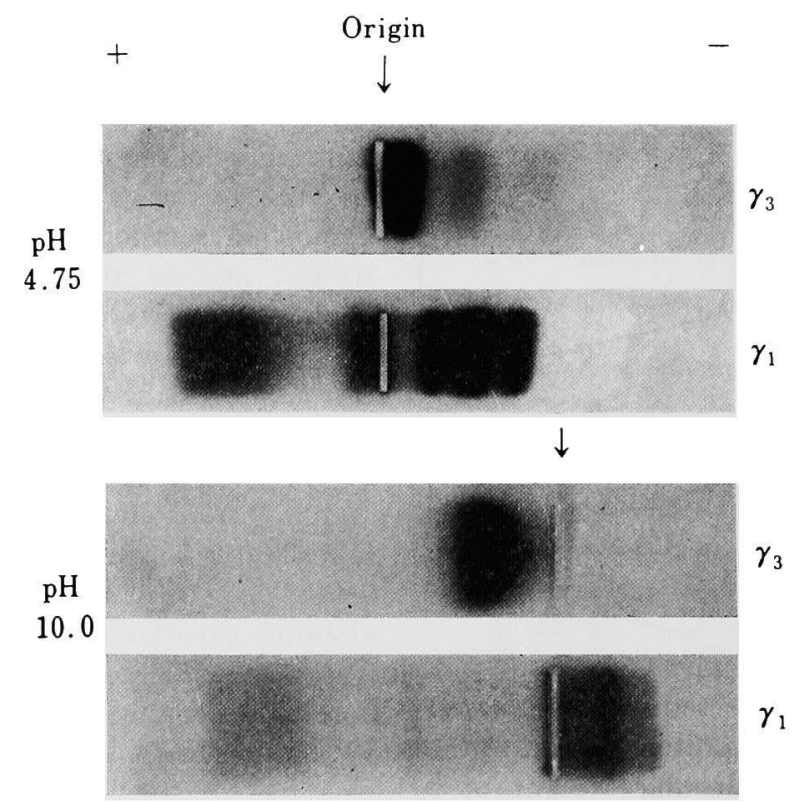

FIG. 6. Polyacrylamide Gel Electropherograms of S-Cyanoethyl $\gamma_{1}$ and $\gamma_{3}$ Globulins in $8 \mathrm{M}$ Urea at $\mathrm{pH} 4.75$ and 10.0 . 
8 shows the semilogarithmic plots of molecular weight against relative mobility. The figures show that $\gamma_{3}$ globulin exhibits a major subunit

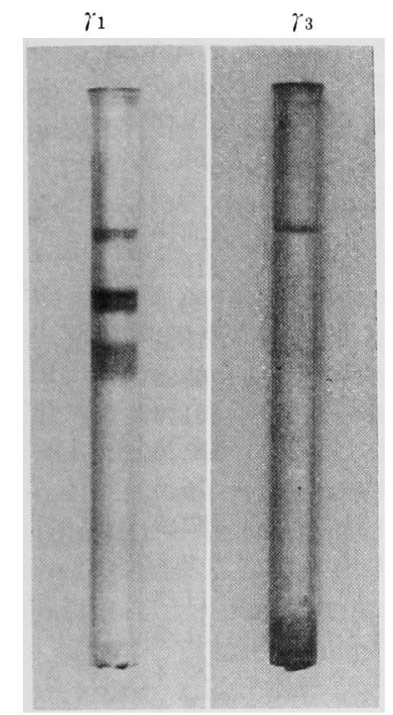

FIG. 7. SDS-Polyacrylamide Gel Electropherograms of $\gamma_{1}$ and $\gamma_{3}$ Globulins.

Experimental details are given in the text. of the molecular weight of 35,000 and a minor subunit of molecular weight of 13,000. Then it will be reasonable to conclude that $\gamma_{3}$ globulin having the molecular weight of 120,000 is composed of 3 major polypeptide chains (mol. wt. 35,000) and 1 minor polypeptide (mol. wt. 13,000). The major polypeptide must have arginine residue as the $\mathrm{N}$-terminus while the minor polypeptide may have glycine or glutamic acid residue. In contrast, it is very interesting to note that $\gamma_{1}$ globulin has a complicated subunit constitution of multiple molecular weight species: $36,000,24,000,21,300$, 14,800 and 13,000 , in addition to the multiplicity in electrophoresis and $\mathrm{N}$-terminal amino acid.

\section{Chemical composition of $\gamma_{3}$ globulin}

The nitrogen content of $\gamma_{3}$ globulin was found to be $17.79{ }^{\circ} \circ$. The protein contained a small amount of carbohydrate. The Tillman's and Bial's reactions showed that $\gamma_{3}$ globulin contained $2.24 \%$ hexose and $0.55 \%$ pentose residues, which were somewhat higher than those of $i_{1}$ globulin. The amino acid
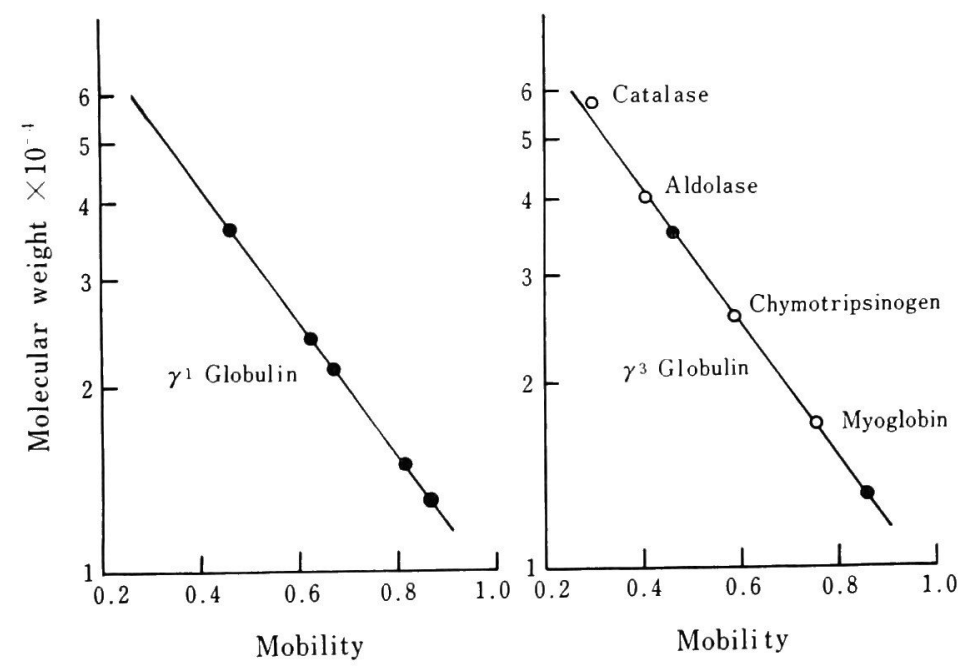

FIG. 8. Determination of Molecular Weights of Subunits of $r_{1}$ and $r_{3}$ Globulins by SDSPolyacrylamide Gel Electrophoresis.

See Fig. 7. Open circles are the molecular weight standards. 
Table I. Amino Acid and Carbohydrate Composition of $\gamma_{3}$ Globulin

\begin{tabular}{|c|c|c|c|c|c|}
\hline $\begin{array}{l}\text { Amino acid or } \\
\text { carbohydrate }\end{array}$ & $\begin{array}{l}\text { Amino acids or } \\
\text { carbohydrates } \\
\mathrm{g} \text { per } 100 \mathrm{~g} \\
\text { of protein }\end{array}$ & $\begin{array}{l}\text { Amino acid or } \\
\text { carbohydrate } \\
\text { residues } \mathrm{g} \text { per } \\
100 \mathrm{~g} \text { of protein }\end{array}$ & $\begin{array}{l}N \text { as per cent } \\
\text { of total } N\end{array}$ & $\begin{array}{c}\text { Calculated No. } \\
\text { of residues } \\
\text { for mol. wt. } \\
120,000\end{array}$ & $\begin{array}{l}\text { No. of } \\
\text { residues to } \\
\text { nearest integer }\end{array}$ \\
\hline Histidine & 4.67 & 4.13 & 7.26 & 36.5 & 37 \\
\hline Lysine & 4.44 & 3.89 & 4.86 & 36.7 & 37 \\
\hline Arginine & 13.22 & 11.84 & 24.38 & 91.8 & 92 \\
\hline Ammonia & $1.01^{a}$ & $0.95^{a}$ & 4.50 & $68.5^{a 1}$ & $69^{a}$ \\
\hline Aspartic acid & 6.57 & 5.68 & 3.97 & 59.8 & 60 \\
\hline Glutamic acid & 19.96 & 17.89 & 9.20 & 138.6 & 139 \\
\hline Glycine & 7.42 & 5.64 & 7.93 & 119.5 & 120 \\
\hline Alanine & 6.09 & 4.86 & 5.48 & 82.7 & 83 \\
\hline Valine & 7.36 & 6.24 & 5.05 & 76.1 & 76 \\
\hline Leucine & 7.54 & 6.50 & 4.62 & 69.6 & 70 \\
\hline Isoleucine & 3.36 & 2.90 & 2.06 & 31.0 & 31 \\
\hline Proline & 5.11 & 4.31 & 3.57 & 53.6 & 54 \\
\hline Serine & 6.65 & 5.52 & 5.08 & 76.6 & 77 \\
\hline Threonine & 3.02 & 2.53 & 2.18 & 32.9 & 33 \\
\hline Methionine & 1.11 & 0.98 & 0.68 & 9.1 & 9 \\
\hline Half cystine & 1.12 & 0.95 & 0.81 & 11.2 & 11 \\
\hline Phenylalanine & 6.99 & 6.23 & 3.40 & 51.2 & 51 \\
\hline Tyrosine & 3.95 & 3.56 & 1.76 & 26.4 & 26 \\
\hline Tryptophan & 1.42 & 1.30 & 0.56 & 8.4 & 8 \\
\hline Total of amino acid & 110.00 & 94.95 & 97.35 & 1011.7 & 1014 \\
\hline Hexosamine & 0.57 & 0.52 & 0.23 & 3.5 & 4 \\
\hline Hexose & 2.49 & 2.24 & & 15.0 & 15 \\
\hline Pentose & 0.64 & 0.55 & & 4.4 & 4 \\
\hline Total & 113.70 & 98.26 & 97.58 & 1034.6 & 1037 \\
\hline
\end{tabular}

a) These values are omitted from the total.

and carbohydrate composition of $\gamma_{3}$ globulin is summarized in Table $I$. The values were obtained by average or extrapolation of the duplicated experimental data of amino acid analysis on 22 and $70 \mathrm{hr}$ hydrolysates, as described in the previous report on $\gamma_{1}$ globulin. ${ }^{51}$ The residue and nitrogen recoveries of the analysis are fairly good, which indicate high reliability of the analysis. The protein has a distinctive feature in amino acid composition of high contents of glutamic acid and arginine as in the case of $\gamma_{1}$ globulin. ${ }^{51}$ The balance between the non-amidized dicarboxylic acids and basic amino acids is compatible with the fact that the protein is a weakly basic protein. Comparing the composition with that of $\gamma_{1}$ globulin, aspartic acid content is lower and leucine and isoleucine contents are slightly higher in $\gamma_{3}$ globulin. The remarkable difference is the absence of hydroxyproline in $\gamma_{3}$ globulin. The higher tryptophan content of $\gamma_{3}$ globulin than $\gamma_{1}$ globulin is also noteworthy. The higher content reflects a higher light absorption in the ultraviolet region, $E_{1 \mathrm{~cm}}^{1 \%}$ at $280 \mathrm{~m} \mu$ of 8.55 , comparing with that of $\gamma_{1}$ globulin, 6.25 .

\section{DISCUSSION}

The molecular weight of $\gamma_{3}$ globulin was found to be 120,000 daltons by both sedimentation equilibrium and gel filtration chromatography. The value is very different from that of $\gamma_{I}$ globulin, 200,000, ${ }^{5 /}$ although both 
proteins exhibit very similar sedimentation coefficient of about 7S. This fact should be derived from the different molecular shapes of the two proteins. Thus $\gamma_{1}$ globulin has a very asymmetric shape having an axial ratio of 14 , while $\gamma_{3}$ globulin has an almost spheric shape. Such a difference in molecular shape must be caused by their characteristic subunit structures. The ten subunits of $\gamma_{1}$ globulin exhibit high multiplicity in the molecular weights, amino termini and electric charges. On the other hand, $r_{3}$ globulin is composed of 3 arginyl polypeptide chains of the molecular weight 35,000 and 1 minor polypeptide of molecular weight 13,000 , although it is still questioned whether the minor subunit might occur originally in the $\gamma_{3}$ globulin or it might associate artificially with the major components during the purification. At any rate, it can be concluded that the subunit structure of $\gamma_{3}$ globulin is simpler than that of $\gamma_{1}$ globulin. The interpretation that the higher structure of $\gamma_{1}$ globulin should be much more complicated than that of $\gamma_{3}$ globulin can be revealed also by the comparison of the electropherograms of the proteins in buffer solution and those of their S-cyanoethyl derivatives in $8 \mathrm{M}$ urea. Thus the dissociation of $\gamma_{1}$ globulin into the subunits after S-cyanoethylation causes large change in the electric charge, but the change in the case of $\gamma_{3}$ globulin is very little.

The structures of $\gamma_{1}$ and $\gamma_{3}$ globulins suggest the different physiological significance of two proteins in rice embryo. Further investigations on chemical and physical properties of the protein as well as the behavior or function in the germination process will be worthwhile.

Acknowledgements. The authors are indebted to Dr.
H. Sawai for his valuable discussions. Rice embryos used in this study were kindly supplied by Okura Shuzo Co. Ltd, Kyoto, to whom thanks are due. This investigation was supported in part by a grant in aid for scientific research from the Ministry of Education.

\section{REFERENCES}

1) Y. Morita and C. Yoshida, Agr. Biol. Chem., 32, 664 (1968).

2) C. E. Danielson, Biochem. J., 44, 387 (1949)

3) J. W. Pence and A. H. Elder, Cereal Chem, 30, $275(1953)$.

4) H. Sawai and 1. Morita, Agr. Biol. Chem., 34, $53(1970)$.

5) H. Sawai and Y. Morita, ibid., 34, 61 (1970).

6) H. Sawai and Y. Morita, ibid., 34, 771 (1970).

7) Y. Morita, H. Sawai, K. Hamaguchi and K. Ikeda, ibid., 35, 1231 (1971).

8) A. C. Beckwith, J. S. Wall and R. W. Jordan, Arch. Biochem. Biophys., 112, 16 (1965).

9) H. Sawai and Y. Morita, Agr. Biol. Chem., 32, 496 (1968).

10) H. Fujita, J. Phys. Chem., 63, 1326 (1959),

11) P. Andrews, Biochem. J., 91, 222 (1964).

12) A. L. Shapiro, E. Vinuela and J. V. Maizel, Biochem. Biophys. Res. Commun., 28, 815 (1967).

13) K. Weber and M. Osborn, J. Biol. Chem., 244, 4406 (1969).

14) D. H. Spackman, W. H. Stein and S. Moore, Anal. Chem., 30, 1190 (1958).

15) E. Schram, S. Moore and E. J. Bigwood, Biochem. J., 57, 33 (1954).

16) T. W. Goodwin and R. A. Morton, ibid., 40, 628 (1946).

17) F. Sanger, ibid., 39, 507 (1945).

18) A. L. Levy, Nature, 174, 126 (1954).

19) R. Archer and C. Crocker, Biochim. Biophys. Acta, 9, 704 (1952).

20) C. J. Weber, J. Biol. Chem., 86, 217 (1930).

21) F. Perrin, J. Phys, Radium, [7] 5, 497 (1934); [7] 7, 1 (1936). 